\title{
Allergic Sensitization Increases Contractile Responses to 5-HT in Guinea Pig Aorta
}

\author{
Patricia CAMPOS-BEDOLLA ${ }^{\mathbf{1}^{*}}$, Rafael DE-LA-CRUZ-NEGRETE ${ }^{\mathbf{1}}$, Mario Humberto \\ VARGAS $^{2,3^{*}}$, Emmanuel Gilberto TORREJÓN-GONZÁLEZ ${ }^{1}$, Dinora MENDOZA-MEJÍA ${ }^{1}$, \\ Azul ISLAS-HERNÁNDEZ ${ }^{1}$, Patricia SEGURA-MEDINA ${ }^{2}$, Guadalupe CÓRDOBA- \\ RODRÍGUEZ ${ }^{2}$, Sandra OROZCO-SUÁREZ ${ }^{1}$, José Luis ARREOLA-RAMÍREZ ${ }^{2}$ \\ * These authors contributed equally to this work.
}

${ }^{1}$ Unidad de Investigación Médica en Enfermedades Neurológicas, Hospital de Especialidades, Centro Médico Nacional Siglo XXI, Instituto Mexicano del Seguro Social, Ciudad de México, México, ${ }^{2}$ Departamento de Investigación en Hiperreactividad Bronquial, Instituto Nacional de Enfermedades Respiratorias, Ciudad de México, México, ${ }^{3}$ Unidad de Investigación Médica en Enfermedades Respiratorias, Hospital de Pediatría, Centro Médico Nacional Siglo XXI, Instituto Mexicano del Seguro Social, Ciudad de México, México

Received January 28, 2019

Accepted August 29, 2019

Epub Ahead of Print December 19, 2019

\begin{abstract}
Summary
Epidemiological and clinical studies suggest that asthma is associated with adverse cardiovascular outcomes, but its mechanism is uncertain. 5-Hydroxytryptamine (5-HT) is a mediator involved in asthma and in cardiovascular functioning. Thus, in the present study, we explored whether allergic sensitization in guinea pigs modifies 5 -HT-induced contractile responses and $5-\mathrm{HT}_{2 \mathrm{~A}}$ receptor expression in thoracic aorta rings. We found that sensitization produced a significant increase of $100 \mu \mathrm{M}$ 5-HT-induced contractions of aorta rings ( $27 \%$ greater contraction than in non-sensitized animals, $\mathrm{p}<0.05)$. Preincubation with $10 \mathrm{nM}$ ketanserin (a $5-\mathrm{HT}_{2 \mathrm{~A}}$ receptor antagonist) reduced by $\sim 30 \%(p=0.003)$ and $\sim 36 \%(p=0.005)$ the area under the curve of $5-\mathrm{HT}$-induced contractions in aortas from non-sensitized and sensitized animals, respectively. There were no differences between sensitized and non-sensitized animals with respect to mRNA (qPCR) and protein (Western blot) expression of $5-\mathrm{HT}_{2 \mathrm{~A}}$ receptor in thoracic aortas. We concluded that in this guinea pig model of asthma, allergic sensitization is not confined to airways, but also affects arterial contractile responses to 5-HT; changes in the expression of the $5-\mathrm{HT}_{2 \mathrm{~A}}$ receptor appear not to be involved in this phenomenon.
\end{abstract}

\section{Key words}

5-HT • Serotonin • 5- $\mathrm{HT}_{2 \mathrm{~A}}$ receptor • Asthma model • Vascular responsiveness $\bullet$ Thoracic aorta $\bullet$ Vascular smooth muscle

\section{Corresponding author}

P. Campos-Bedolla, Unidad de Investigación Médica en Enfermedades Neurológicas, Centro Médico Nacional Siglo XXI, Instituto Mexicano del Seguro Social, Av. Cuauhtémoc 330, Col. Doctores, CP 06720, Ciudad de México, México. Fax: (55)-55780240. E-mail: camposbedollap@hotmail.com

Asthma is characterized by exaggerated airway contractile responses to a variety of physical or chemical stimuli. A number of inflammatory mediators have been proposed as being involved in the pathophysiology of asthma, but to date the role of 5-hydroxytryptamine (5-HT, serotonin) has been relatively poorly investigated. In animals, 5-HT induces airway smooth muscle contraction (Long et al. 2009), blockade of the 5- $\mathrm{HT}_{2 \mathrm{~A}}$ receptor by ketanserin decreases allergen-induced airway hyperreactivity (De Bie et al. 1998), and plasma 5-HT levels are increased in sensitized animals compared with non-sensitized controls (Arreola-Ramirez et al.

PHYSIOLOGICAL RESEARCH • ISSN 1802-9973 (online) 
2013). Although inhaled 5-HT proved to have weak or negligible bronchoconstrictor activity in healthy or asthmatic subjects (Tønnesen 1985), more recent studies suggest that 5-HT participates in human asthma. For example, Lechin et al. (1996) found that free plasma levels of 5-HT were increased in asthmatic patients and correlated with the severity of the disease, and that tianeptine, a drug that potentiates 5-HT uptake, improved pulmonary function in asthmatic children (Lechin et al. 1998).

Some reports indicate that patients with asthma are at an increased risk for developing cardiovascular diseases (CVD) as compared with nonasthmatic subjects (Iribarren et al. 2004, Tattersall et al. 2015). In this context, the involvement of 5-HT in different physiological processes of the cardiovascular system is widely recognized, including the generation of bradycardia or tachycardia, hypotension or hypertension, and the modulation of vascular resistance with vasoconstriction or vasodilation (Saxena and Villalón 1990). These apparently opposing effects are due to the large variety of 5-HT receptors, including 14 subtypes grouped in seven families (5-HT $1-7$ ) (Pytliak et al. 2011). The increased levels of 5-HT found in patients with asthma (Lechin et al. 1996) could partially explain the higher cardiovascular risk documented in these patients. Moreover, allergic sensitization might induce additional mechanisms that lead to the potentiation of 5-HT responses. For example, mRNA expression of $5-\mathrm{HT}_{2 \mathrm{~A}}$ and $5-\mathrm{HT}_{3 \mathrm{~A}}$ receptors in peripheral blood mononuclear cells appear to be higher in patients with asthma, as compared with control subjects (Ahangari et al. 2015). In contrast, mRNA expression of the $5-\mathrm{HT}_{2 \mathrm{~A}}$ receptor in CD4+ T-cells is reduced in patients with asthma as compared with healthy subjects (Chen et al. 2016). In animal models, the protein expression of $5-\mathrm{HT}_{2 \mathrm{~A}}$ and $5-\mathrm{HT}_{4}$ receptors in guinea pig lung was found to be increased after systemic sensitization with ovalbumin (OVA) (Cordoba-Rodriguez et al. 2016).

The present work aimed to investigate modifications of the aorta contractile responses to 5-HT in a guinea pig model of OVA-induced allergic asthma, and the potential role of the $5-\mathrm{HT}_{2 \mathrm{~A}}$ receptor.

Male Hartley guinea pigs (500-600 g body weight) bred under conventional conditions in our institutional animal facilities were used (National Research Council (US) 2011). The protocol was approved by the Scientific and Bioethics Committees of the Instituto Nacional de Enfermedades Respiratorias (approval No. B10-13) and the Instituto Mexicano del Seguro Social (approval No. R-2013-3601-7). Experiments were performed following international guidelines for the use and care of laboratory animals.

Animals were deeply anesthetized with pentobarbital (35 $\mathrm{mg} \cdot \mathrm{kg}^{-1}$, intraperitoneally) and exsanguinated. The thoracic aorta was dissected and four rings were obtained (each ring was submitted to different experimental conditions). Each aorta ring was hung in a 5-ml organ bath with Krebs solution and attached to an isometric transducer (model HDW100A, Biopac Systems Inc., Santa Barbara, CA, USA). Isometric transducers were connected to a preamplifier (model MP150, Biopac), signals were digitized and monitored through the Acknowledge 3.9.1 software.

Tissues were placed under a resting tension of $1.5 \mathrm{~g}$ during $20 \mathrm{~min}$, followed by three successive conditioning stimulations with $80 \mathrm{mM} \mathrm{KCl}$. All responses to 5-HT were expressed as the percentage of the third $\mathrm{KCl}$ response. Temporal evolution of single concentrations of 5 -HT $(0.1,1,3.2,10,32$, and $100 \mu \mathrm{M})$ was evaluated in separate aorta rings. Based on these responses, subsequent experiments were carried out utilizing $100 \mu \mathrm{M}$ 5-HT. Some tissues were preincubated during $15 \mathrm{~min}$ with $10 \mathrm{nM}$ ketanserin (an antagonist of the $5-\mathrm{HT}_{2 \mathrm{~A}}$ receptor) before adding 5-HT. Because 5-HT is a light-sensitive chemical compound, all experiments were performed under darkness conditions.

The guinea pigs were sensitized at day 0 with $60 \mu \mathrm{g}$ OVA and $1 \mathrm{mg} \mathrm{Al}(\mathrm{OH})_{3}$ in $0.5 \mathrm{ml}$ saline $(0.9 \%$ $\mathrm{NaCl})$, equally applied by the intraperitoneal and subcutaneous routes. At days 8 and 15, animals were nebulized with $3 \mathrm{mg} \cdot \mathrm{ml}^{-1} \mathrm{OVA}$ in saline during $5 \mathrm{~min}$, and with $1 \mathrm{mg} \cdot \mathrm{ml}^{-1}$ OVA in saline during $1 \mathrm{~min}$, respectively. Guinea pigs were studied on days 21-25.

Total RNA was extracted from aorta tissue using TRIzol reagent (Cat. 10296028, Life Technologies, Grand Island, NY, USA). Quality of RNA obtained was evaluated by resolution on denatured $1 \%$ agarose gels and measurement of 260/280 nm absorbance ratios. Synthesis of complementary DNA (cDNA) was performed by using $1 \mu \mathrm{g}$ of total RNA, $1 \mu \mathrm{g}$ of DNase and $1 \mu \mathrm{l}$ Buffer DNase (Cat. EN0523, Fermentas, Waltham, MA, USA), and reverse-transcribed (High-Capacity cDNA Reverse Transcription Kit with RNase Inhibitor, Cat. 4374966, Applied Biosystems, Carlsbad, CA, USA). qPCR amplification was accomplished in a i-Cycler iQ Detection System (Bio-Rad Laboratories Inc., Hercules, CA, USA). Primers for the $5-\mathrm{HT}_{2 \mathrm{~A}}$ receptor were designed in 
Probefinder (http://qpcr.probefinder.com/organism.jsp) with the primer sense and antisense sequences 5'CTGCAGGATGATTCCAAGGT'3 and 3'AAATGCCACGAAAGAACCAA'5, respectively. 18S rRNA was used as an internal control gene (Cat. 4352930E, Applied Biosystem). All qPCR determinations were performed in triplicate. Individual values were log-transformed to obtain a normal distribution, and the relative expression of the $5-\mathrm{HT}_{2 \mathrm{~A}}$ receptor, as compared with the expression of the internal control gene (18S rRNA) in the same tissue, was calculated by the $2^{-\Delta \mathrm{CT}}$ formula. In addition, the relative expressions of the $5-\mathrm{HT}_{2 \mathrm{~A}}$ receptor in tissues from sensitized guinea pigs were compared with those observed in non-sensitized animals by employing the $2^{-\Delta \Delta \mathrm{CT}}$ method.

Western blotting analysis was performed to detect $5 \mathrm{HT}_{2 \mathrm{~A}}$ receptor expression in aorta tissues. Proteins were extracted using lysis buffer and their concentrations were measured using the DCTM Protein Assay Kit (Bio-Rad). Proteins in a $60 \mu \mathrm{g}$ sample were separated by polyacrylamide gel electrophoresis (SDS-PAGE), electrotransferred onto a polyvinylidene fluoride (PVDF) membrane (Bio-Rad) and blocked with $3 \%$ skim milk in TBS-T at $4{ }^{\circ} \mathrm{C}$ overnight. Membranes were incubated during $120 \mathrm{~min}$ at room temperature with goat polyclonal antibody against the $5-\mathrm{HT}_{2 \mathrm{~A}}$ receptor $(1: 1000$; sc-15073; Santa Cruz Biotechnology, Inc., Dallas, TX, USA) or with mouse monoclonal antibody against GAPDH (1:1500; sc-47724, Santa Cruz Biotechnology, Inc., Dallas, TX, USA), the latter utilized as an internal control. The secondary antibody (1:15000) was peroxidase horse antigoat (PI-9500) and anti-mouse IgG (PI-200) (Vector Laboratories, Burlingame, CA, USA). Protein bands were identified by means of chemiluminescence (Luminata ${ }^{\mathrm{TM}}$ Classico Western HRP Substrate, Millipore Corporation, Billerica, MA, USA) and measured by densitometry employing the ImageJ software.

Contractile responses to 5-HT were evaluated in two ways: at each 2-min time-interval, and as the whole area under the curve. After corroborating the normal distribution of data (Kolmogorov-Smirnov test), the nonpaired Student's $t$-test was used to evaluate differences in responses to 5-HT between sensitized and non-sensitized tissues and, in separate experiments, to evaluate the effect of ketanserin. Statistical significance was set at one-tailed $\mathrm{p}<0.05$, and the data were reported as the mean \pm standard error of the mean.

Increasing concentrations of 5-HT produced timeand concentration-dependent sustained contractions in guinea pig aortas ( $n=5-6$ per group, data not shown). From these curves, we decided to use a $100 \mu \mathrm{M}$ 5-HT concentration in subsequent experiments because at this concentration we obtained the highest contractile response.

Compared with non-sensitized animals $(n=7)$, contractile responses to $100 \mu \mathrm{M}$ 5-HT were increased in sensitized animals $(n=5)$ (Fig. 1A), reaching statistically significant differences from $10 \mathrm{~min}$ onward. According to the area under the curve, responses in sensitized tissues represented $\sim 27 \%$ greater contraction than in control animals $(p=0.04)$.
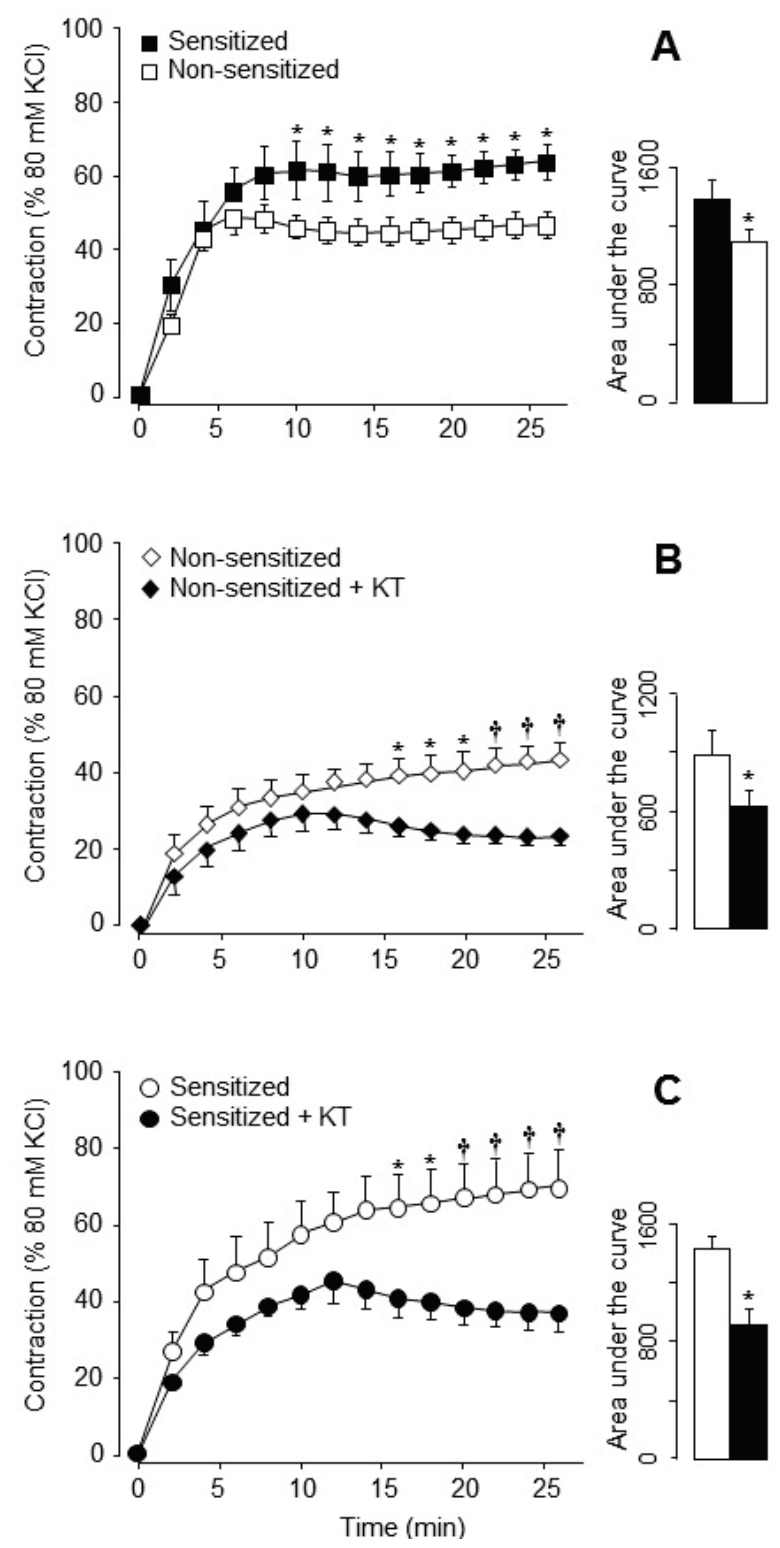

Fig. 1. Modifications of the contractile responses to $5-\mathrm{HT}$ by allergic sensitization and ketanserin in guinea pig thoracic aorta rings. Allergic sensitization to ovalbumin caused increased contractile responses to $100 \mu \mathrm{M}$ 5-HT (A). Preincubation with the $5-\mathrm{HT}_{2 \mathrm{~A}}$ receptor antagonist ketanserin $(\mathrm{KT}, 10 \mathrm{nM})$ diminished the contractile response to $100 \mu \mathrm{M} 5-\mathrm{HT}$ in either non-sensitized (B) and sensitized (C) tissues. Symbols correspond to the mean \pm standard error of $n=5-7$ experiments per group. ${ }^{*} p<0.05$ and ${ }^{\dagger} p<0.01$ (Student's $t$-test). 
In separate experiments, the effect of ketanserin was evaluated in sensitized and non-sensitized tissues. In aortas from non-sensitized guinea pigs, preincubation with $10 \mathrm{nM}$ ketanserin caused a notable diminution of the 5-HT-induced contraction, which reached statistical significance from 12 min onward ( $\mathrm{n}=6$ per group) (Fig. 1B). Globally, this change represented $\sim 30 \%$ diminution of the area under the curve $(p=0.003)$. This same trend was also observed in aortas from sensitized animals, in which ketanserin caused a noticeable decrease of 5-HT-responses, especially from 14 min onward ( $n=6$ per group, $p<0.01$ ) (Fig. 1C), and the area under the curve diminished $\sim 36 \%(\mathrm{p}=0.005)$.

According to the qPCR analysis by means of the $2^{-\Delta \Delta \mathrm{CT}}$ method, the mRNA relative expression of the $5-\mathrm{HT}_{2 \mathrm{~A}}$ receptor in aortas from sensitized guinea pigs $(n=5)$ corresponded to 0.296 of the relative expression in non-sensitized animals (reference value $=1, n=4$ ). However, this apparent diminution lacked statistically significant differences ( $\mathrm{p}=0.74)$ (Fig. 2A).

There was no significant difference in the relative expression (target protein/control protein) of the $5-\mathrm{HT}_{2 \mathrm{~A}}$ receptor from non-sensitized guinea pigs $(0.83 \pm 0.07, \mathrm{n}=6)$ with respect to the sensitized group $(0.95 \pm 0.05, n=7)$, with a $\mathrm{p}=0.17$ (Fig. $2 \mathrm{~B}$ ).

In the present work, we found that allergic sensitization increases the aorta contractile responses to 5-HT. This suggests that, at least in this guinea pig model of asthma, the effect of the allergic process is not solely confined to airways or lung parenchyma, but goes beyond the latter to affect the cardiovascular system as well.

Clinical experience and epidemiological studies have shown that asthma and CVD often coincide in the same patients. Several reports revealed that patients with asthma had an increased prevalence of CVD (Bellocchia et al. 2013), with a $32 \%$ to $60 \%$ higher risk for CVD occurrence when compared with persons without asthma (Iribarren et al. 2012, Tattersall et al. 2015, Tattersall et al. 2016, Wang et al. 2017). Although it has been argued that the association of asthma and CVD may be simply explained because both conditions share the same risk factors, it is also possible that a cause-effect relationship exists in this association. A potential mediator involved in this link is 5-HT, inasmuch as this mediator appears to be involved in the pathogenetic processes of both asthma and CVD. Thus, clinical studies have demonstrated that plasma levels of 5-HT were elevated in a variety of CVD-related pathologies, including hypertension, coronary artery disease, valvular heart disease, atherothrombosis, atherosclerosis, and myocardial infarction (Kaumann and Levy 2006). Likewise, increased 5-HT blood levels were found in patients with asthma (Lechin et al. 1996), as well as in animal models of asthma (Segura et al. 2010, ArreolaRamirez et al. 2013). Moreover, platelets constitute the major source of 5-HT in blood, and it is known that, in humans, these elements are involved in disorders of the cardiovascular system (Papapanagiotou et al. 2016), as well as in asthma (Idzko et al. 2015).|
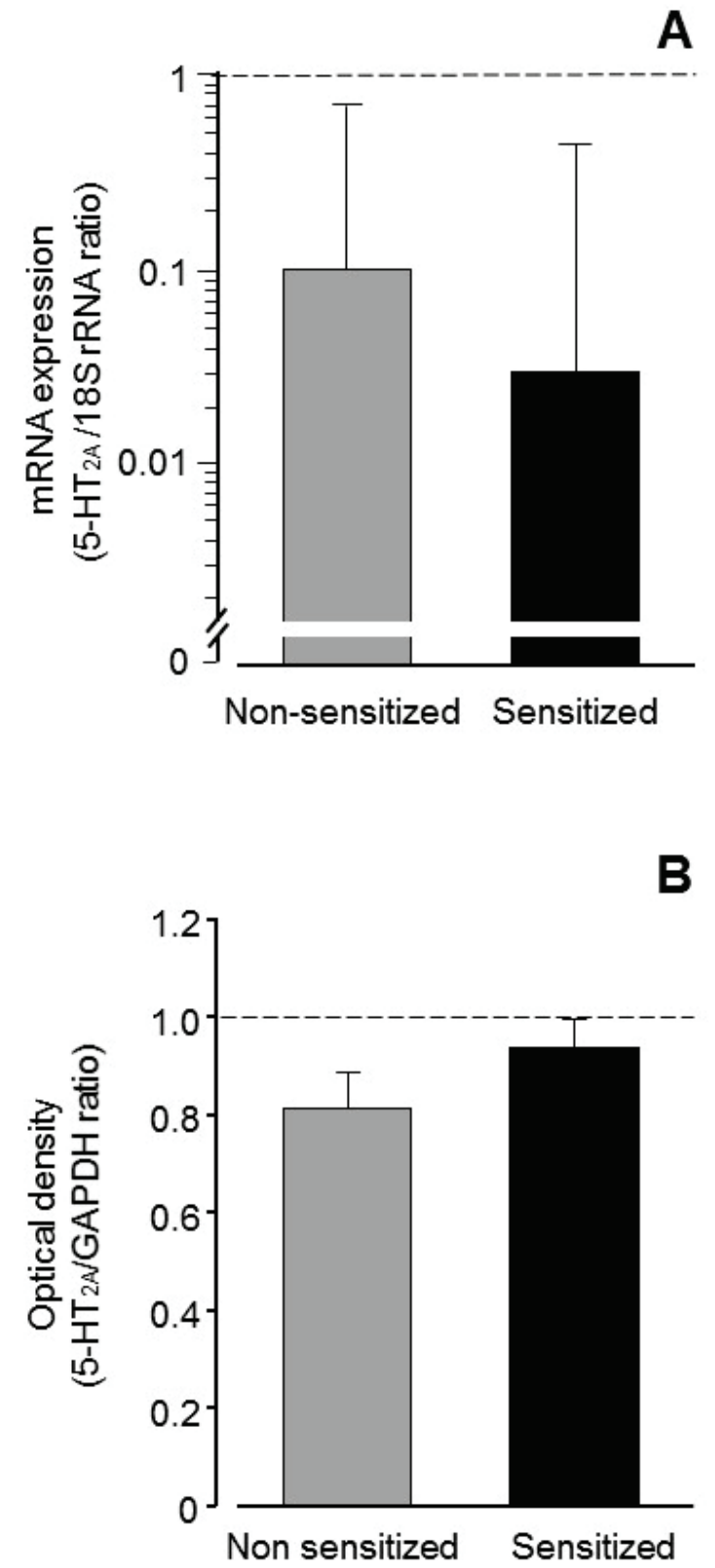

Fig. 2. Effect of allergic sensitization to ovalbumin on the mRNA (A) and protein (B) expression of the $5-\mathrm{HT}_{2 \mathrm{~A}}$ receptor in guinea pig thoracic aortas. Bars and vertical lines correspond to the geometric mean \pm standard error, respectively, of $n=4-6$ (nonsensitized) or $n=5-7$ (sensitized) experiments. There was no statistically significant difference between non-sensitized and sensitized animals. 
A number of studies support the concept that 5- $\mathrm{HT}_{2 \mathrm{~A}}$ receptors mediate 5-HT-induced vascular smooth muscle contraction in arterial blood vessels (McKune and Watts 2001). In this context, in the present work, our first approach comprised assessing whether allergic sensitization causes an increase in $5-\mathrm{HT}_{2 \mathrm{~A}}$ receptor expression. We did not find statistically significant modifications in the amount of mRNA or protein expressions. Some alternative mechanisms for explaining these increased responses might be speculated upon. Allergic sensitization might enhance intracellular signaling mechanisms, for example, through the generation of reactive oxygen species (ROS), leading to enhanced responsiveness to 5-HT (Rubanyi and Vanhoutte 1986, Lounsbury et al. 2000, Zuo et al. 2013, Qu et al. 2017). On the other hand, although the main mechanism by which 5-HT produces vascular smooth muscle contraction is stimulation of the $5-\mathrm{HT}_{2 \mathrm{~A}}$ receptor and activation of Gq proteins (Misarkova et al. 2016), this response might be modified by the simultaneous effect of 5-HT on other 5-HT receptors, such as the prejunctional $5-\mathrm{HT}_{3}, 5-\mathrm{HT}_{4}$, and $5-\mathrm{HT}_{7}$ receptors (Segura et al. 2010). Thus, sensitization could be changing expression or functionality of these latter receptors, instead of the expression of the $5-\mathrm{HT}_{2 \mathrm{~A}}$ receptor.

We found that ketanserin only inhibited a relatively moderate portion of the response, mainly in its second half. This result clearly indicates that factors other than $5-\mathrm{HT}_{2 \mathrm{~A}}$ receptor activation were responsible for the major part of the serotoninergic contractile response. Notably, the effect of ketanserin was relatively the same in sensitized and in non-sensitized animals, indicating that the $5 \mathrm{HT}_{2 \mathrm{~A}}$ receptor-independent contractile response to 5 -HT was not affected by allergic sensitization.

In conclusion, our results revealed that in this asthma model, allergic sensitization was not confined to airways, but it also affected arterial responses to 5-HT, given rise to increasing contractile responses. Modifications of $5-\mathrm{HT}_{2 \mathrm{~A}}$ receptor expression appear not to be involved in this phenomenon.

\section{Conflict of Interest}

There is no conflict of interest.

\section{Acknowledgements}

We thank Dr. I. Grijalva for his support in the development of this research. This study was supported by funding provided by Fondo de Investigacion en Salud of the Instituto Mexicano del Seguro Social with a grant number FIS/IMSS/PROT/G14/1300 to Dr. P. CamposBedolla.

\section{References}

AHANGARI G, KOOCHAK SE, AMIRABAD LM, DEILAMI GD: Investigation of 5-HT2A gene expression in PBMCs of patients with allergic asthma. Inflamm Allergy Drug Targets 14: 60-64, 2015. https://doi.org/10.2174/1871528114666150803152433

ARREOLA-RAMIREZ JL, VARGAS MH, MANJARREZ-GUTIERREZ G, ALQUICIRA J, GUTIERREZ J, CORDOBA G, CAMPOS-BEDOLLA P, SEGURA-MEDINA P: Modifications of plasma 5-HT concentrations during the allergic bronchoconstriction in guinea pigs. Exp Lung Res 39: 269-274, 2013. https://doi.org/10.3109/01902148.2013.805855

BELLOCCHIA M, MASOERO M, CIUFFREDA A, CROCE S, VAUDANO A, TORCHIO R, BOITA M, BUCCA C: Predictors of cardiovascular disease in asthma and chronic obstructive pulmonary disease. Multidiscip Respir Med 8: 58, 2013. https://doi.org/10.1186/2049-6958-8-58

CORDOBA-RODRIGUEZ G, VARGAS MH, RUIZ V, CARBAJAL V, CAMPOS-BEDOLLA P, MERCADILLOHERRERA P, ARREOLA-RAMIREZ JL, SEGURA-MEDINA P: Allergic sensitization modifies the pulmonary expression of 5-hydroxytryptamine receptors in guinea pigs. Respir Physiol Neurobiol 223: 9-15, 2016. https://doi.org/10.1016/j.resp.2015.11.018

CHEN RZ, ZHU M, WANG T, JI YL: Expression of serotonin receptor and transporter related genes of CD4+ T lymphocytes in patients with asthma and depression. (In Chinese) Sichuan Da Xue Xue Bao Yi Xue Ban 47 : 222-226, 2016.

DE BIE JJ, HENRICKS PA, CRUIKSHANK WW, HOFMAN G, JONKER EH, NIJKAMP FP, VAN OOSTERHOUT AJ: Modulation of airway hyperresponsiveness and eosinophilia by selective histamine and 5-HT receptor antagonists in a mouse model of allergic asthma. $\mathrm{Br} \mathrm{J}$ Pharmacol 124: 857-864, 1998. https://doi.org/10.1038/sj.bjp.0701901 
IDZKO M, PITCHFORD S, PAGE C: Role of platelets in allergic airway inflammation. J Allergy Clin Immunol 135: 1416-1423, 2015. https://doi.org/10.1016/j.jaci.2015.04.028

IRIBARREN C, TOLSTYKH I, VEISNER MD: Are patients with asthma at increased risk of coronary heart disease? Int J Epidemiol 33: 743-748, 2004. https://doi.org/10.1093/ije/dyh081

IRIBARREN C, TOLSTYKH IV, MILLER MK, SOBEL E, EISNER MD: Adult asthma and risk of coronary heart disease, cerebrovascular disease, and heart failure: a prospective study of 2 matched cohorts. Am J Epidemiol 176: 1014-1024, 2012. https://doi.org/10.1093/aje/kws181

KAUMANN AJ, LEVY FO: 5-hydroxytryptamine receptors in the human cardiovascular system. Pharmacol Ther 111: 674-706, 2006. https://doi.org/10.1016/j.pharmthera.2005.12.004

LECHIN F, VAN DER DIJS B, OROZCO B, JARA H, RADA I, LECHIN ME, LECHIN AE: Neuropharmacologic treatment of bronchial asthma with the antidepressant tianeptine: a double-blind, crossover placebo-controlled study. Clin Pharmacol Ther 64: 223-232, 1998. https://doi.org/10.1016/S0009-9236(98)90156-4

LECHIN F, VAN DER DIJS B, OROZCO B, LECHIN M, LECHIN AE: Increased levels of free serotonin in plasma of symptomatic asthmatic patients. Ann Allergy Asthma Immunol 77: 245-253, 1996. https://doi.org/10.1016/S1081-1206(10)63263-2

LONG JW, YANG XD, CAO L, LU SM, CAO YX: Alteration of airway responsiveness mediated by receptors in ovalbumin-induced asthmatic E3 rats. Acta Pharmacol Sin 30: 965-972, 2009. https://doi.org/10.1038/aps.2009.61

LOUNSBURY KM, HU Q, ZIEGELSTEIN RC: Calcium signaling and oxidant stress in the vasculature. Free Radic Biol Med 28: 1362-1369, 2000. https://doi.org/10.1016/S0891-5849(00)00222-7

MCKUNE CM, WATTS SW: Characterization of the serotonin receptor mediating contraction in the mouse thoracic aorta and signal pathway coupling. J Pharmacol Exp Ther 297: 88-95, 2001.

MISARKOVA E, BEHULIAK M, BENCZE M, ZICHA J: Excitation-contraction coupling and excitation-transcription coupling in blood vessels: their possible interactions in hypertensive vascular remodeling. Physiol Res 65: 173-191, 2016.

NATIONAL RESEARCH COUNCIL (US): Guide for the Care and Use of Laboratory Animals. Washington (DC). 2011.

PAPAPANAGIOTOU A, DASKALAKIS G, SIASOS G, GARGALIONIS A, PAPAVASSILIOU AG: The role of platelets in cardiovascular disease: molecular mechanisms. Curr Pharm Des 22: 4493-4505, 2016. https://doi.org/10.2174/1381612822666160607064118

PYTLIAK M, VARGOVÁ V, MECHÍROVÁ V, FELSÖCI M: Serotonin receptors - from molecular biology to clinical applications. Physiol Res 60: 15-25, 2011.

QU J, LI Y, ZHONG W, GAO P, HU C: Recent developments in the role of reactive oxygen species in allergic asthma. J Thorac Dis 9: E32-E43, 2017. https://doi.org/10.21037/jtd.2017.01.05

RUBANYI GM, VANHOUTTE PM: Superoxide anions and hyperoxia inactivate endothelium-derived relaxing factor. Am J Physiol 250: H822-H827, 1986. https://doi.org/10.1152/ajpheart.1986.250.5.H822

SAXENA PR, VILLALÓN CM: Cardiovascular effects of serotonin agonists and antagonists. J Cardiovasc Pharmacol 15 (Suppl 7): S17-S34, 1990. https://doi.org/10.1097/00005344-199000157-00004

SEGURA P, VARGAS MH, CÓRDOBA-RODRÍGUEZ G, CHÁVEZ J, ARREOLA JL, CAMPOS-BEDOLLA P, RUIZ V, GARCÍA-HERNÁNDEZ LM, MÉNDEZ C, MONTAÑO LM: Role of 5-HT2A, 5-HT4 and 5-HT7 receptors in the antigen-induced airway hyperresponsiveness in guinea-pigs. Clin Exp Allergy 40: 327-338, 2010. https://doi.org/10.1111/j.1365-2222.2009.03412.x

TATTERSALL MC, BARNET JH, KORCARZ CE, HAGEN EW, PEPPARD PE, STEIN JH: Late-onset asthma predicts cardiovascular disease events: The Wisconsin Sleep Cohort. J Am Heart Assoc 5: pii: e003448, 2016. https://doi.org/10.1161/JAHA.116.003448

TATTERSALL MC, GUO M, KORCARZ CE, GEPNER AD, KAUFMAN JD, LIU KJ, BARR RG, DONOHUE KM, MCCLELLAND RL, DELANEY JA, STEIN JH: Asthma predicts cardiovascular disease events: the multi-ethnic study of atherosclerosis. Arterioscler Thromb Vasc Biol 35: 1520-1525, 2015. https://doi.org/10.1161/ATVBAHA.115.305452 
TØNNESEN P: Bronchial challenge with serotonin in asthmatics. Allergy 40: 136-140, 1985. https://doi.org/10.1111/j.1398-9995.1985.tb02673.x

WANG L, GAO S, YU M, SHENG Z, TAN W: Association of asthma with coronary heart disease: A meta analysis of 11 trials. PLoS One 12: e0179335, 2017. https://doi.org/10.1371/journal.pone.0179335

ZUO L, OTENBAKER NP, ROSE BA, SALISBURY KS: Molecular mechanisms of reactive oxygen species-related pulmonary inflammation and asthma. Mol Immunol 56: 57-63, 2013. https://doi.org/10.1016/j.molimm.2013.04.002 